\title{
TITLE INSURANCE: THE DUTY TO SEARCH
}

A DEFECr in ownership or title is said to exist when the aggregate of rights, privileges, powers, and immunities known as ownership is subject to the claims of others. ${ }^{1}$ Such claims may restrict the use which can be made of the property and as a corollary may reduce its market value. ${ }^{2}$ The possible types of title defects are myriad. Some defects will be disclosed by a search of the public transfer records; others will be disclosed only by a physical examination or a survey of the property itself; still others may remain undisclosed even after physical examination and consultation of public records. ${ }^{3}$ Often the existence of title defects will depend upon complex and confusing legal doctrines. ${ }^{4}$ Since the average layman has neither the skill nor the means to discover or protect himself against all possible defects in his title, he must

1. The concept of ownership as a bundle of rights, powers, privileges, duties, and immunities has often been expressed. See, e.g., Biodgetr, Comparative Economic Systems 24 (1944); Gage, Land Titze Assuring AgEncIEs 17 (1937) [hereinafter cited as Gage]; Restatement, Property §§ 1-10 (1936).

Absolute ownership of all the bundle of rights by a single individual would be difficult to find since ownership is subject to such governmental claims as taxes, zoning, and eminent domain, as well as being subject to public interest claims through the common law doctrine of nuisance. See Prosser, Torts \$ 70 (2d ed. 1955); Hunt, Federal and State Cantrol of Land: A Synopsis, in McDougal \& Haber, Property, Wealth, Land: Allocation, Planning \& Development 70, 75, 83-90 (1948). To any given interest holder these claims, as well as adverse rights held by another person, are defects in his ownership bundle. See GaGE 19-23; McKillop, Title Insurance, 8 U. FLA. L. Rev. 447, 448 (1955).

2. See, e.g., W. F. White Land Co. v. Christenson, 14 S.W.2d 369 (Tex. Civ. App. 1928) (restrictive covenant in deed coupled with a defeasance clause); Wilkinson v. Nassau Shores, Inc., 1 Misc. 2d 917, 86 N.Y.S.2d 603 (1949) (easement); BASYE, Clearing Land Titres \$ 5, at 16 (1953) [hereinafter cited as Basye].

3. Where tax liens must be filed before attachment for example, a search of the public records will disclose the existence of such a defect. See United States v. City of New Britain, 347 U.S. 81 (1954). But where a tax lien or priority arises without the need to file, searching the records will not disclose the defect. See Core, Tax Forfeiture Problems in the Examination of Abstracts, 12 ARK. L. Rev. 333 (1958); Title News, Jan. 1959, pp. 62-65. Similarly, where mechanics' or materialmens' liens must be recorded before attachment, search of the public records will discover the defects. However, as in the more usual case, when such liens relate back to the date of commencement of work or furnishing of materials, physical inspection of the property and not mere search of the public records is necessary to ensure full discovery of this type of defect. See Comment, 68 Y ALE L.J. 138 (1958) ; OsBoRne, Mortgages § 214 (1951). For examples of different statutory treatment of the priority of mechanics' liens, see N.Y. LIEN LAw $\$ 13$ and ORE. Rev. Stat. $\$ \S 87.025$ (1) \& (2) (1953). Encroachments and other possessory rights of long standing which through the doctrine of adverse possession have become legally protected also necessitate physical inspection or a survey. See, e.g., Sinfes, The Inprovement of Conveyancing By Legislation 37, 44 (1960).

4. The nature of defects and their discovery often depend upon local property law, recording statutes, or the prevailing method of holding property. See generally GAGE 34; Smith, Insurance of Titles to Property, 8 J. LAND \& P.U. Econ. 337 (1932). 
rely upon a specialized individual or institution. 5 In recent years title insurance has become an increasingly widespread means of answering this need. ${ }^{\circ}$ However, because title insurance characteristically combines search and disclosure with insurance ${ }^{7}$ protection in a single operation, confusion has resulted as to the exact nature and extent of the title insurance company's obligations beyond those as insurer.

It might seem that attempting to resolve the question whether a title company has a legal duty to search ${ }^{8}$ is engaging in meaningless verbalism, since the company is already liable under the insurance contract. In many situations, however, finding a duty to search may increase the liability of the title company. The insured may be able to recover damages in excess of the face amount of the policy. ${ }^{9}$ The insured may also recover damages where no recovery would be possible on the insurance contract, because the duty to search may extend to items not expressly covered by insurance provisions. ${ }^{10}$ There may even be recovery for a defect of a type covered by a

5. To a layman a.search is a mystery, and the various pitfalls that may beset his title are dreaded, but unknown. To avoid a possible claim against him, to obviate the need and expense of professional advice, and the uncertainty that sometimes results even after it has been obtained, is the very purpose for which the owner seeks insurance.

Empire Dev. Co. v. Title Guarantee \& Trust Co., 225 N.Y. 53, 57, 121 N.E. 468, 470 (1918). See GAGE 34.

6. Johnstone, Title Insurance, 66 YALE L.J. 492, 493 (1957) ; Zerfing, Title Insurance and Its Background, Title News, Oct. 1953, pp. 16-22.

7. A variety of semantic problems lies hidden in the apparent simplicity of the generic term "insurance." Various commentators have stated that title insurance is solely indemnification insurance. See, e.g., 1 Richards, Insurance $\$ 32$ (5th ed. 1952); Pelkey, The Law of Title Insurance, 12 Marq. L. Rev. 38, 43 \& nn.25-31 (1927). The cases do not wholly bear out this oversimplification. See, e.g., Maggio v. Abstract Title \& Mortgage Corp., 277 App. Div. 940, 98 N.Y.S.2d 1011 (1950) (in the nature of a guarantee or wager) ; Empire Dev. Co. v. Title Guarantee \& Trust Co., 225 N.Y. 53, 121 N.E. 468 (1918) (in the nature of a warranty). Courts seemingly adopting the indemnification definition have sometimes verbalized the problem on a different level by varying the definition of "loss." Compare Foehrenbach v. German-American Title \& Trust Co., $217 \mathrm{~Pa} .331,66$ Atl. 561 (1907), with Udell v. City Title Ins. Co., 12 App. Div. 2d 78, 208 N.Y.S.2d 504 (1960).

8. Implicit in the duty to search is a duty to disclose; search without disclosure would be generally meaningless from the owner's point of view. Consequently the "duty to search" as used in this Note will include both search and disclosure obligations.

9. See Quigley v. St. Paul Title Ins. \& Trust Co., 60 Minn. 275, 62 N.W. 287 (1895), comected case, 64 Minn. 149, 66 N.W. 364 (1896); Mezzaluna v. Jersey Mortgage \& Title Guar. Co., 109 N.J.L. 340, 162 Atl. 743 (1932); Annot., 60 A.L.R.2d 972 (1958); letter from F. W. Audrain, Chief Counsel, Security Title Insurance Company, Los Angeles, California, to the Yale Law Joumal, April 24, 1961, on file in Yale Law Library ("tort liability has no limit as to what might be charged against the title insurer").

Implicit in awarding the insured greater damages than the face amount of the policy is the idea that the face amount applies only to the insurance provisions and not to the implied or express search provisions.

10. Greater recovery may be possible because: (1) should a tort theory of liability be adopted for breach of the duty to search, the scope of proximately caused damages would 
blanket exception clause or for a defect specifically excepted in the policy. ${ }^{11}$ Finding a duty to search may also enable the insured to avoid conditions in the policy. For example, he may circumvent the standard insurance contract condition that before recovery is allowed loss must be actually realized rather than merely accrued. ${ }^{12}$ Similarly, conditions providing for notice may be avoided. ${ }^{13}$

It seems helpful to approach the basic question of whether an obligation to search exists in addition to insurance obligations by examining the historical development of title insurance. ${ }^{14}$ The simplest and oldest method of assuring title is the title attorney's search and opinion. He examines the public records, weighs the facts in light of existing law, and then renders his opinion as to the condition of title. ${ }^{15}$ An outgrowth of the title attorney method, the abstracter system, differs but little from the earlier institution. ${ }^{16}$ Neither of these methods adequately protects the individual against possible future losses since the scope of duty owed to the client is only that of reasonable care

usually be broader than that for breach of a contractual undertaking. PROSSER, TORTS $\S 81$, at 478 (2d ed. 1955); and (2) the scope of a "reasonable search" may be broader than the terms of the insurance policy itself. See Henkels v. Philadelphia Title Ins. Co., 177 Pa. Super. 110, 110 A.2d 878 (1955) (item excepted from insurance policy was not excepted from scope of duty to search).

11. If a duty to search is imposed on the title insurer, the question of whether a subsequently discovered defect causing loss to the insured will give rise to liability will turn on whether a reasonable search would have discovered the defect, and not on whether that defect fell outside of the broad classes of hard-to-discover defects usually excepted from the policy. Even where the defect is specifically exempted in the policy, this may not satisfy the reasonable searcher's duty to disclose fully the nature and legal effect of the defect. Thus in Dorr v. Massachusetts Title Ins. Co., 238 Mass. 490, 131 N.E. 191 (1921), there was recovery for a defect expressly excepted in the subsequently issued insurance policy because circumstances were such that the title company should reasonably have given notice of the defect.

12. See Blessing v. American Title \& Ins. Co., 121 So. $2 d 455$ (Fla. 1960); Booth v. New Jersey Highway Authority, 60 N.J. Super. 534, 159 A.2d 460 (1960); Udell v. City Title Ins. Co., 12 App. Div. 2d 78, 208 N.Y.S.2d 504 (1960) (dictum); Pelkey, The Lawe of Title Insurance, 12 MARQ. L. REv. 38, 51 \& nn.61-63 (1927). Such conditions may also be avoided by the simple expedient of ignoring them. See Fifth Mut. Bldg. Soc'y of Manayunk's Appeal 317 Pa. 161, 176 At1. 494 (1935).

13. Compare Houston Title Guar. Co. v. Fontenot, 339 S.W.2d 347, 353 (Tex. Civ. App. 1960) (amount expended by insured prior to notice not recoverable as a matter of law), with Kentucky Title Co. v. Hail, 219 Ky. 256, 266, 292 S.W. 817, 822 (1927) (under implied contract to search insured did not have to satisfy condition precedent before recovering). Exact compliance with notice requirements may also be avoided by the doctrines of anticipatory breach, repudiation, or waiver. See, e.g., Purcell v. Land Title Guar. Co., 94 Mo. App. 5, 67 S.W. 726 (1902); American Fidelity Cas. Co. v. Williams, 34 S.W.2d 396 (Tex. Civ. App. 1930).

14. For an excellent discussion of the causes leading to the development of title insurance, see GAGE 78-85. See also West, History of Title Insurance, Title News, Jan. 1957, p. 8; Rhodes, The Insurance of the Real Estate Title, 10 Conn. B.J. 115 (1936).

15. GAGE 39-42, 47-49.

16. Id. at $42-43$. 
in making a title search. Thus there is no liability for defects which cannot be discovered with reasonable care. ${ }^{17}$ Title insurance purported to remedy this inadequacy by insuring against losses from defects not disclosed by a reasonable search. ${ }^{18}$ This insurance function might have developed separately from searching. In fact, however, because title insurance was a natural outgrowth of the previous searching institutions and because any insuring agency would desire to appraise the risks involved before insuring, the early title insurance company typically performed the title search as well..$^{10}$

The combination of search and insurance exists today in a variety of forms. The majority of title insurers operate as "title-plant companies," maintaining duplicates of the public records and carrying out their own independent searches. ${ }^{20}$ This form of organization displaces the ordinary practitioners from the title examination process and substitutes the insurance policy for the lawyer's opinion. ${ }^{21}$ A second form of company, typified by the Lawyers' Title Guaranty Fund, issues what have been called "lawyer-title policies."22

17. Such defects may spring from two major sources: (1) facts which are not discoverable by a reasonable search. See, e.g., National Savings Bank v. Ward, 100 U.S. 195 (1879); Adams v. Greer, 114 F. Supp. 770,775 (W.D. Ark. 1953) ; (2) discoverable facts which may be improperly evaluated by what would nonetheless be a reasonable exercise of an attorney's or abstracter's opinion. See, e.g., Toth v. Vazquez, 3 N.J. Super. 379, 65 A.2d 778 (1949); Watson v. Muirhead, $57 \mathrm{~Pa} .161,98 \mathrm{Am}$. Rep. 213 (1868). See generally Wade, The Attorney's Liability for Negligence, 12 VAND. L. Rev. 755, 774 (1959) ; Roady, Professional Liability of Abstracters, 12 VAND. L. Rev. 783 (1959).

18. It has been said that the establishment in 1876 of the first title insurance company in America, the Real Estate Title Insurance Company, resulted as a reaction to the Pennsylvania Supreme Court's restriction of the scope of conveyancer's liability in the celebrated case of Watson v. Muirhead, $57 \mathrm{~Pa} .161,98 \mathrm{Am}$. Rep. 213 (1868). See GAGE 80-85; see generally Public Regulation of Title Insurance Companies and Abstracters \$ 0.30, at 13-14 (Roberts ed. 1961) [hereinafter cited as VILLANOVA REPORT].

19. The dual purpose of the early companies is indicated by the initial advertisement of the first title insurance company:

"The company insures the purchasers of real estate and mortgages against loss from defective titles, liens, and encumbrances.

"It has at its command the knowledge and experiences of the leading coveyancers of this city as well as the information relative to real estate title accumulated by them during many years past....

"Insurances are effected only after a thorough examination and search as to encumbrances."

Gage 82; see North \& Van Buren, Reai Estate Titres \& Conveyancing 248 (1940) [hereinafter cited as NoRTH \& VAN BUREN].

20. See Norte \& Van Buren 248, 251 (1940) ; Payne, The Why, What, and How of Uniform Title Standards, 7 ALA. L. Rev. 25, 27 (1954).

21. Payne, supra note 20 , at 27.

22. Lawyers' Title Guaranty Fund was developed by Florida lawyers in order to give their clients the same protection against "non-apparent" and "undisclosed" risks as does the more usual form of title insurance. Carter, Lawyers' Title Guaranty Fund, 8 U. Fid. L. REv. 480-81 (1955).

A similar company, the Lawyers' Title Insurance Company of Richmond, is the major company writing such policies on a nationwide basis. See Johnstone, supra note 6 , at $505 \&$ 
Such policies are issued on the basis of applications from lawyers who have performed the traditional search rather than on the basis of independent investigations of title by the company itself..23 A third form of company, very similar to the second, insures title on the basis of an abstract furnished by an approved abstract company. ${ }^{24}$ "Title-plant companies" adopt both the second and third forms of organization in extending their business into geographic areas in which they do not have title plants. ${ }^{25}$ Still another organizational form appears to be developing: there have been reports of title insurers who issue policies on the basis of little or no preliminary title search. ${ }^{26}$ This development reflects the ultimate in the casualty or actuarial approach. The distinctions between these various combinations of search and insurance are blurred by variations in the operations of and scope of coverage afforded by each company. ${ }^{27}$

The protean variety of forms and practices, coupled with changes in the wording of title policies ${ }^{28}$ and changes in searching methods, ${ }^{29}$ has under-

n.52. Apparently Virginia is the only state in which the use of title insurance based on attorney searches predominates. See Report of the CoMmitree on Acceptable Titres To Real Property, Proc. A.B.A. Sec. Real Prop., Prob. \& Trust Law 43, 50 (1953).

23. See Payne, supra note 20, at 26-27.

Considering the inefficiency of many states' public records, it may be doubtful whether title insurance based upon an attorney's search can survive in competition with a "titleplant company" unless the attorneys adopt some superior method of record keeping such as the title plant or exert sufficient legislative pressure to cause improvements in the keeping of public records. See North \& Van Buren 50-51, 225-26; Thompson, Abstracts \& TrTLES § 98, at 186 (1930). But see Johnstone, supra note 6, at 517.

24. NORTH \& VAN BUREN 248.

25. See ibid; Payne, supra note 20, at 26; Johnstone, supra note 6, at 505, 523-24.

26. See, e.g., Tarpley, The Future of Title Isusurance, Title News, Oct. 1959, p. 24; Report of Chairmen of Regional Districts, Title Instrance Bxecutive-1957-1958 Administration, Title News, Jan. 1959, p. 102; Curtis, Title Insurance, Converting from Abstracts to Title Insurance, Title News, May 1953, pp. 2-3. Competition is probably the primary reason for the increase in casualty type title insurance. See Beiniker, Why We Behave Like Titlemen, Title News, July 1959, pp. 14, 19.

27. See notes 48-49 infra and accompanying text.

28. The history of the Chicago Title \& Trust Company exemplifies the type of wording changes which make definition of the title companies' undertaking more difficult. Until 1933 the company issued a preliminary report which stated :

Our examination of the title to the property hereinafter described is completed to include [a certain date] and on said date we find title of record in....

Reeve, Guaranteenng Marketability of Titles to Real. Estate 98 (1951) [hereinafter cited as REEvE]. Because of pressures from the local Bar Association which expressed views that the Company was practicing law by making such a judgment, the Company changed to their present statement of readiness to issue a title policy and of the items which the policy would contain. Id. at 99 . Such a change in working makes far less clear the intent of the title company to make a title seach for the benefit of the insured.

29. As the insurance companies have increased the scope of risks insured against, they have kept an ever-widening range of records. See Johnstone, supra note 6 , at 507 . This collateral expansion of recorded materials has encompassed areas in which it is far from certain that a reasonable search could or should be made, and accordingly may obfuscate the 
standably engendered confusion concerning the nature and extent of the title insurer's duty to search. ${ }^{30}$ In facing (or avoiding) the question courts have "come up with many and diverse results." 31 In the absence of an express promise to search title, some courts have looked to circumstances surrounding the issuance of the policy and implied from these a duty to search. ${ }^{32} \mathrm{~A}$ large number of cases, however, predicate liability solely in terms of indemnification or insurance. ${ }^{33}$ It is not always clear whether the failure to discuss or

extent of the insurer's duty to search. See notes 78-82 infra and accompanying text. To offset the danger of an expanded duty title companies have introduced exculpatory clauses into their policies and preliminary papers, thus further confusing the question of their search function. See notes 50-51 infra and accompanying text. Perhaps the greatest changes in searching methods, however, have been the making of limited searches by companies relying on policies previously issued by other insurers and the abandonment of a search by a few companies operating on a purely actuarial basis. See Johnstone, supra note 6, at 516 ; note 26 supra.

30. Compare J. H. Trisdale, Inc. v. Shasta County Title Co., 146 Cal. App. 2d 831, 304 P.2d 832 (1956) (both tort and contract causes of action upheld on demurrer), with Maggio v. Abstract Title \& Mortgage Corp., 227 App. Div. 940, 98 N.Y.S.2d 1011 (1950) ("doctrine of skill or negligence has no application" to title insurer's liability). Compare Kentucky Title Co. v. Hail, 219 Ky. 256, 292 S.W. 817 (1927) (company discovered error in description and was under a duty to disclose), with Sala v. Security Title Ins. \& Guarantee Co., 27 Cal. App. 2d 693, 81 P.2d 578, 582 (1938) (company discovered lis pendens but had "right to include or omit a reference to the lis pendens ... as it chose").

The uncertainty has not gone altogether unnoticed by the title industry:

What representations do we make in the issuance of the policy? Is there a representation of the nature of the examination? If there is such a representation-is there liability in the nature of an abstractor's [sic] liability over and above the liability of an insurer under the terms of the policy?

Howlett, $A$ Look at Title Losses ant Liability Assumed, Title News, Jan. 1960, pp. 76, 78.

31. Hawkins v. Oakland Title Ins. \& Guar. Co., 165 Cal. App. 2d 116, 125, 331 P.2d 742,747 (1958).

32. In one case, for example, a duty to search was implied from a letter sent by the title company to the client stating that title had been examined and that a policy of insurance would subsequently be issued. On this basis the court found that:

[The company] undertook to act for plaintiff in two capacities-as a conveyancer, who examined the title and undertook to advise her whether it was good and marketable, and as an insurer, who undertook to insure that she had a good and marketable title. In the former capacity, the [company] assumed the same responsibilities and owed to the plaintiff the same duty as if it had been an individual attorney or conveyancer.

Glyn v. Title Guarantee \& Trust Co., 132 App. Div. 859, 861-62, 117 N.Y. Supp. 424, 426-27 (1909). See Dorr v. Massachusetts Title Ins. Co., 238 Mass. 490, 131 N.E. 191 (1921); Ehmer v. Title Guarantee \& Trust Co., 156 N.Y. 10, 50 N.E. 420 (1898).

33. E.g., Diel v. Security Title Ins. Co., 142 Cal. App. 2d 808, 298 P.2d 873 (1956); Russell \& Co. v. Polk County Abstract Co., 87 Iowa 233, 54 N.W. 212 (1893); Pioneer Title Ins. \& Trust Co. v. Cantrell, 71 Nev. 243, 286 P.2d 261 (1955); Hilfor v. United States Mortgage \& Title Guar. Co., 14 N.J. Super. 456, 82 A.2d 463 (1951) ; Montemarano v. Home Title Ins. Co., 258 N.Y. 478, 180 N.E. 241 (1932); Fifth Mut. Bldg. Soc'y of Manayunk's Appeal, 317 Pa. 161, 176 Atl. 494 (1935) ; Buquo v. Title Guar. \& Trust Co., 20 Tenn. App. 479, 100 S.W.2d 997 (1936). 
find liability for negligent search results from the plaintiff's failure to plead a good cause of action in negligence or from a determination that the liability of the company rests solely on the insurance policy and that the policy itself does not create a duty to search. ${ }^{34}$

In attempting to resolve the confusion over the existence of a duty to search, at least four alternatives are open to the courts :

(1) finding in the title policy or accompanying papers an express contract to search the title;

(2) finding from the circumstances surrounding the issuance of the policy an implied-in-fact contract to search;

(3) finding in the relationship of the parties a duty to search ; or

(4) finding that the title policy is limited solely to an insurer's contract to insure good title with no undertaking and no duty to search.

As the fourth alternative is merely the result of rejecting the other three, it requires no separate analysis here. Moreover, only the first two alternatives seem to fall readily within traditional contract doctrines, and their feasibility thus warrants careful consideration before the third alternative is reached.

If a court could find an express undertaking to search title-the first alternative suggested-no question would arise concerning the existence of a duty to search. The title policy itself, except in rare instances, makes no mention of a search, ${ }^{35}$ and there is generally no separate employment contract containing a specific undertaking to search title. ${ }^{36}$ It may be possible, however, to find an express undertaking in the papers issued prior to the insurance contract. These preliminary papers may take a variety of forms. For example, the insured may simply receive a letter stating that a policy will be issued or that

34. See, e.g., Hocking v. Title Ins. \& Trust Co., 37 Cal. 2d 644, 234 P.2d 625 (1951); Booth v. New Jersey Highway Authority, 60 N.J. Super. 534, 159 A.2d 460 (1960).

The court in Hocking held that the insured's complaint failed to state a cause of action, apparently deciding-with no direct discussion of negligence-that the insured's loss was not within the policy coverage. The opinion is unclear as to whether the failure to state a cause of action was due to the fact that the company was not negligent or to the fact that negligence was irrelevant in a suit by an insured policyholder.

Booth in contrast discussed but did not find liability for negligence. The complaint, which alleged both tort and contract causes of action, was dismissed. It is not clear whether the decision was based upon the court's conclusion that the "contract of title insurance, as distinguished from that of employment to examine the title to premises, does not involve liability for negligence," or its conclusion that the insured "knew of the uncertainty" and consequently did not rely upon the alleged negligent action of the title company, or, finally, its finding that there was "no proof whatsoever of any loss or damage to the plaintiff." 60 N.J. Super. at 538 , 159 A.2d at 461-62.

35. None of the standard policies recommended by the American Title Association expressly mentions a title search. See Virianova Report, apps. A \& B. For further examples of title policies see Johnstone, supra note 6, at 521-24; ReEvE 229-40.

36. The failure in the overwhelming majority of the cases to mention the existence of a separate contract to search title would seem to indicate no such separate contract is made. But see Henkels v. Philadelphia Title Ins. Co., 177 Pa. Super. 110, 113, 110 A.2d 878, 880 
title has vested in him subject to certain defects, or he may receive a more formal report or certificate of title. ${ }^{37}$ Though the preliminary papers may expressly state that the insurer has duly searched the title and discovered the defects noted, ${ }^{38}$ they will usually be ambiguous as to the undertaking to search. ${ }^{39}$ In many instances, moreover, these papers explicitly state that the liability under the certificate is limited to the issuance of a title policy. ${ }^{40}$ Thus, the alternative of grounding a duty to search on an express contractual undertaking is not ordinarily available.

In the absence of an express promise, a court must consider the second alternative-whether there is an implied-in-fact contract to search title. One may argue that the insurance policy and preliminary papers suggest the existence of such a contract. The policy itself generally insures against loss or damage from defects in title subject to certain exceptions set out in the policy and in the preliminary papers. ${ }^{41}$ The listing of defects in the particular title would seem to imply that a search was made to discover these defects. ${ }^{42}$

(1955) (separate oral contract); Kentucky Title Co. v. Hail, 219 Ky. 256, 292 S.W. 817, 818 (1927) (separate contract implied from fact insurer was to receive $3 / 4$ of fee if no policy issued for "its time and expense in the investgiation of the title"); Title Ins. Co. v. Industrial Bank, 156 Va. 322, 157 S.E. 710 (1931) (court manufactured a separate undertaking out of pure fiction).

37. See Carrier, The Customer's Viewpoint, Title News, Jan. 1960, p. 60. The author categorizes the four main types of preliminary papers in current use: (1) a preliminary letter showing a report of title but stating that there is no liability thereunder; (2) a letter stating that a policy of insurance will be issued; (3) an interim insurance binder stating that title is vested in a certain person subject only to certain enumerated defects and further stating that the interim binder will be "null and void" upon subsequent issuance of the policy; (4) a commitment to insure which is similar to an interim binder but lists certain general exceptions besides showing specific defects. For illustrative forms see NoRTH \& VAN BUREN 201-08.

38. See GaGE 70-71; ReEvE 63, 69. For examples of such statements see, e.g., Metropolitan Title Guarantee Co. v. Gildenhorn, 249 F.2d 933, 935 n.5, 937 (D.C. Cir. 1957); M.R.M. Realty Co. v. Title Guarantee \& Trust Co., 270 N.Y. 120; 200 N.E. 666 (1936).

39. See, e.g., Title Ins. \& Trust Co. v. City of Los Angeles, 61 Cal. App. 232, 234-36, 214 Pac. 667, 668-69 (1923) ; Marandino v. Lawyers' Title Ins. Corp., 156 Va. 696,159 S.E. 181 (1931) ; cf. Carrier, supra note 37, at 63 ("None of these preliminary title reports gives a person who is purchasing a home for the first time sufficient information to determine what he should do to see that his interests are fully protected.").

40. Thus in Udell v. City Title Ins. Co., 12 App. Div. 2d 78, 208 N.Y.S. $2 d 504$ (1960), the title certificate stated:

[T] he Company's liability ... under this certificate is limited to the issuance of a policy of title insurance as of closing day in its usual form for the amount stated below and this certificate shall become null and void upon the issuance of such policy."

Defendant-Appellant's Brief, pp. 26-27 [on file Yale Law Library]. A similar provision was involved in Union Realty Co. v. Ahern, 93 A.2d 84 (D.C. Munic. Ct. App. 1952).

41. See notes 35 and 37 supra.

42. See, e.g., Miller v. Lawyers' Title Ins. Corp., 112 F. Supp. 221 (E.D. Va. 1953); Marandino v. Lawyers' Title Ins. Corp., 156 Va. 696, 159 S.E. 181 (1931). But see Pioneer Title Ins. Co. v. Cantrell, 71 Nev. 243, 286 P.2d 261 (1955). 
However, a listing of some defects does not necessarily mean that these are the only defects, and thus such a listing may not constitute a representation that a complete search has been made. ${ }^{43}$ The use of blanket clauses excepting general classes of defects also weakens any inference of an undertaking to search title. ${ }^{44}$ This ambiguity may require turning from construction of the contract and preliminary papers to consideration of the practices which were employed in writing the insurance. One technique, employed in some cases, is to characterize the various functions assumed by title companies-for example, the actual searching of title, the writing of contracts, and the transfer and recording of deeds-as analogous to those performed by an attorney and consequently to hold the insurance company to the same title-searching duties as an attorney. ${ }^{45}$ Advertising to the effect that title insurance is the "only complete service" may well strengthen such an inference. ${ }^{46}$ This functional analogy is somewhat weakened, however, by decisions holding that a title insurance company may not practice law. ${ }^{47} \mathrm{~A}$ better technique would be to examine the practices employed by the company in the specific case and on that basis determine both the reasonable man's expectations as to the scope of his contract and the "manifested" intent of the company. ${ }^{48}$ For example, inquiry should be made as to how extensive a title search, if any, the title company has actually made in the past, whether the title company maintains a title plant,

43. An additional factor militating against the implication of a search from a listing of exceptions lies in the fact that insurance companies which have made a search commonly do not list defects which are so minor as to be de minimis. See REEvE 72-73, 77. This omission suggests that the companies themselves do not consider listing of defects as equivalent to a representation that a search has been made.

44. Since the company is specifically denying liability in the areas excepted, it would seem reasonable to suppose the company is also failing to perform an expensive search operation in such areas. Insofar as such areas may be within the scope of a reasonable search, blanket exception seems to deny that a reasonable search was made.

45. See Bridgeport Airport Inc. v. Title Guar. \& Trust Co., 111 Conn. 537, 150 Atl. 509 (1930); Sandler v. New Jersey Realty Title Ins. Co., 66 N.J. Super. 597, 169 A.2d 735 (1961); Mezzaluna v. Jersey Mortgage \& Title Guar. Co., 109 N.J.L. 340, 162 At1. 743 (1932) ; Glyn v. Title Guarantee \& Trust Co., 132 App. Div. 859, 117 N.Y. Supp. 424 (1909).

46. See Movietime-A.T.A., Title News, Sept. 1960, pp. 20-32 (includes still shots from the movie "A Place Under the Sun"); Title News, May 1960, pp. 18-19 (advertisement); Let Title Insurance Help You Build and Sell Houses, Title News, Dec. 1961, pp. $2,3,4-5$.

47. See, e.g., Title Guar. Co. v. Denver Bar Ass'n, 135 Colo. 423, 312 P.2d 1011 (1957); New Jersey State Bar Ass'n v. Northern N.J. Mortgage Ass'n, 32 N.J. 430, 161 A.2d 257 (1960); but see Bar Ass'n of Tenn., Inc. v. Union Planter's Title Guar. Co., 326 S.W.2d 767, 780-81 (Tenn. App. 1959).

48. No broad generalization concerning specific practices can be made since there is "great diversity ... in different sections of the country" and wide variance even within one same area. REEVE 101 ; see id. at 96-108. Thus judicial inquiry into the specific practices employed by the title company would seem necessary for an intelligent interpretation of that company's title insurance policy. See Sala v. Security Title Ins. \& Guarantee Co., 27 Cal. App. 2d 693, 81 P.2d 578 (1938). 
whether a separate charge is made for the search or whether a charge is made even in the event that a title insurance policy is not subsequently issued, and what representations the company has made in its advertising and solicitations. ${ }^{49}$ The opinions in title insurance cases indicate that most courts are failing to make such inquiries.

Even where it is possible to find an express or implied contractual undertaking to search title, a court may be faced with an attempt by the company to disclaim in the written contract itself any liability other than that specified in the insurance policy. ${ }^{50}$ In order to escape the burden of making a thorough title search, title companies may also expressly deny liability for defective title search in preliminary papers. The insurer often states in these papers that his liability is restricted to the subsequent issuance of an insurance policy. ${ }^{51} \mathrm{Al}-$ though this exculpation may avoid the danger of the customer being misled, such evasion of liability for negligent searching may be so unfair and undesirable as a matter of public policy that it should be prohibited. ${ }^{52}$

It is arguable that neither the insured nor society is injured in the long

49. Such inquiries are of the type usually made by courts interpreting contracts whose meaning is not clear. The court should attempt to place itself, as nearly as possible, in the position of the parties to the contract. Chesapeake \& Potomac Tel. Co. v. Murray, 84 A.2d 870 (Md. App. 1952); see generally Restatement, Contracts \$\$ 226-36 (1932); 3 Corbin, Contracts $\$ \S 555-56$ (2d ed. 1960).

50. An example of the type of language is set forth in Sandler v. New Jersey Realty Title Ins. Co., 66 N.J. Super. 597, 601, 169 A.2d 735, 737 (1961) :

[O]bligation and liability ... hereunder shall be limited to and established in the manner provided by, and the amount of loss ... shall be ascertained in accordance with, the scope and conditions of this policy .... and not otherwise.

The American Title Association Standard Owner's Policies contain the following clause:

Any action or actions or rights of action that the Insured may have or may bring against the Company arising out of the status of the title insured herein must be based on the provisions of this policy.

VILLANOVA REPORT, app. B, at 317, 328.

51. See note 40 supra.

52. Determination of the validity of such exculpation clauses appears to depend ultimately upon balancing the freedom of contract against the possible harm to the public resulting from allowing such exculpation. See Jackson v. First Nat'l Bank, 415 Ill. 453, 459-60, 114 N.E.2d 721, 725 (1953). The specific rationale adopted in declaring exculpatory clauses invalid seems to vary with the laws of particular states. Consider for example the states of Illinois and New Hampshire. Illinois seems to predicate invalidity of exculpation clauses on "an obvious public interest in the relationship" coupled with inequality of bargaining power. See, e.g., O'Callaghan v. Waller \& Backwith Realty Co., 15 IIl. 2d 436, 438, 444, 155 N.E.2d 545, 546, 549 (1958). New Hampshire, in comparison, appears to find contracts attempting to relieve a party from liability for negligence contrary to public policy and hence invalid on the basis that erosion of legislatively or judicially imposed duties should be prevented. See Papakalos v. Shaka, 91 N.H. 265, 18 A.2d 377 (1941); Wessman v. Boston \& M. R.R., 84 N.H. 475, 478-79, 152 At1. 476, 479 (1930). It would seem that if a duty to search title is imposed on the title insurer, subsequent exculpation should be denied no matter whether the touchstone be public harm, inequality of bargaining power, or prevention of erosion of judicially or legislatively imposed duties. 
run by exculpation since the insured may procure a title search from another agency once he is explicitly told that he may not rely upon the insurer for a search. ${ }^{53}$ Such an argument overlooks the fact that insurers commonly make some search in order to estimate or decrease the risks involved in insuring a particular piece of land. ${ }^{54}$ The insured pays for this search in the form of higher premiums. ${ }^{55}$ To force the insured to pay for these services and not reap their benefits seems economically wasteful; to force him to pay again, this time to a third party, in order to rely upon the findings of a search seems clearly unfair. ${ }^{56}$ To the extent that exculpation necessitates an additional search, the resources allocated to search may be needlessly doubled. When the insured is forced to turn to another agency for title searching, this agency must either duplicate the high cost recording system of a title plant ${ }^{57}$ or else use the notoriously inefficient public records. ${ }^{58}$ In either case resources are misallocated: duplication frustrates efficiency by preventing intensive use of high fixed cost facilities; utilization of the public records forces the insured and society to pay for an inefficient method of search. Finally, the argument overlooks the fact that in those states and cities where title insurance is most used, the insured may in effect have no alternative agency to which to turn for a title search. ${ }^{59}$ In such a case, to the extent that title insurers exculpate themselves, the choice is either to impose a duty of search on the title insurer regardless of exculpation or to withhold the benefits of a search from the insured.

53. Alternative agencies which may be available include the title attorney, the private abstracter, the abstract company, and-in a few states-public abstract offices.

54. See ReEve 51-87; Gage 86-89.

55. Searching costs consume the major portion of the premium dollar. GAGE 104-15; Comment, 39 CALIF. L. REv. 235, 247-48 (1951) ; Deatly, Give Thanks For Title Insurance, Title News, Feb. 1960, pp. 11, 14.

56. As we view the matter it would be strange, indeed, if prospective purchasers of real property could not rely upon title reports for which they are required to pay, but must search the records themselves. If such be the law a large part of the value of title companies would disappear.

J. H. Trisdale, Inc. v. Shasta County Title Co., 146 Cal. App. 2d 831, 839, 304 P.2d 832, 837 (1956).

57. GAGE 45-46, 150; Johnstone, Title Iinsurance, 66 Y $\mathrm{Y}_{\text {AIE }}$ L.J. 492,507 (1957). Duplication might not be necessary if title companies made their records available to all those who needed them. Except in extremely rare instances, this "open-door" policy does not exist. See Johnstone, supra at 506-07; VILLANOVA REPORT $\$ 0.30$, at $16 \mathrm{n} .2$ ("novel arrangement" in Georgia).

58. See Gage 34-38, 45; McDougal \& Haber, Property, Wealth, Land : Allocation, Planning \& Developarent 117-18 (1948); Comment, 68 Yale L.J. 1245-51 (1959).

59. In California, Oregon, and Washington, title insurance is so dominant that other title assurance methods have generally disappeared. Russell \& Bridewell, Systems of Land Title Examination, 14 J. LAND \& P.U. Econ. 133, 134 (1938); Henley, The New Title Insurance Policy Form, Title News, Sept. 1960, p. 2 ("II]n California . . . title insurance is now completely dominant"). In various other states and cities, title insurance has largely taken over the title business. See REport of the Comartites on AcCEPTABLe Titles To Reat Property, Proc. A.B.A. Sec. Real Prop., Prob. \& Trust Law 43-51 (1953). 
The advisability of permitting exculpation and the proper construction of an ambiguous contractual undertaking both ultimately turn on the desirability or non-desirability of a title search. In resolving this issue a connected-in fact almost obverse-issue must first be considered : does insurance coverage alone adequately protect the insured? Various commentators have answered this question with a resounding "no."60 They point out that very little, if any, insurance protection is actually given since title policies usually except defects actually discovered and make blanket exceptions for various types of hard-todiscover defects. ${ }^{61}$ In assessing the validity of this criticism one must distinguish between the two standard types of policies-the mortgagee policy and the owner's policy. Unlike the typical individual owner, the large, wellorganized institutional lender is in a strong bargaining position in relation to title companies, and the scope of insurance protection it extracts is almost always broader than that given an owner. ${ }^{62}$ Moreover, even if the insurance coverage were the same for both classes of policies, insurance protection alone would be less adequate for owners than for mortgagees. The mortgagee looks at the property primarily as security for his investment. Thus if the mortgagee received insurance in the amount of his mortgage covering all possible defects, insurance might be adequate. For the owner, however, even complete insurance coverage for all defects would seem to be inadequate. As indicated previously, conditions in the policy may prevent recovery until the property is sold or until adverse legal claims are made or may even prevent any recovery at all. ${ }^{63}$

60. Roady, Professional Liability of Abstracters, 12 VAND. L. Rev. 783, 794 (1959) ("title insurance ... a snare and a delusion for many policies written today exclude from coverage the very risks that a vendee desires insured."); GAGE 99-102; MCDougal \& Brabner-Smith, Land Title Transfer: A Regression, 48 YALE L.J. 1125 (1939); of. Bordwell, The Resurrection of Registration of Title, 7 U. CHI. L. REv. 470 (1940); McDougal, Title Registration \& Land Law Reform: A Reply, 8 U. CHI. L. REv. 63 (1940).

61. See articles cited note 60 supra; NORTH \& VAN BUREN 251.

The practice of excepting discovered defects would seem far less injurious to the insured than is the making of blanket exceptions. In the former situation, it is at least arguable that the insured, once informed of the defect, can protect himself by seeking a release, or by quieting title, or even by simply refusing to take the encumbered property. In the case of blanket exceptions, however, as in the case of exculpation, the insured will either have to pay a second agency to search title or perhaps even be forced to go without protection. See notes 57-59 supra and accompanying text.

62. See Johnstone, supra note 57, at 495-96, 504; VILLANOVA REPORT $\$ 0.20$, at 8-12; REEVE 48. For example, mortgagee policies usually insure against unmarketable title whereas owners' policies generally do not. Compare ATA Standard Loan Policy-Revised Coverage -1960, with ATA Owner's Policy-Standard Form A,-1960. VIILANova ReporT, app. A, at 296-306, app. B, at 309-19. Marketability coverage is available in the ATA Owner's Policy-Standard Form B-1960 (additional coverage) for an added price. Id. at 319-28; see Henley, The Neze Title Insurance Policy Form, Title News, Sept. 1960, pp. 2, 10. There are indications, however, that this policy is not being widely used. Report of Atlantic Coast Regional Conference, Title News, Jan. 1961, pp. 118, 120.

63. See notes 12 and 13 supra and accompanying text; Kuhlman v. Title Ins. Co., 177 F. Supp. 925 (W.D. Mo. 1959) ; Sandler v. New Jersey Realty Title Ins. Co., 66 N.J. Super. 597, 169 A.2d 735 (1961). 
When the insurance is written for less than the fair market value of the property, limitation of damages to the face amount of the policy may prevent full recovery of loss. ${ }^{64}$ Finally, even full recovery of money damages may be inadequate. Money alone is poor compensation for infringement of a new home owner's privacy because of an undiscovered easement. ${ }^{65}$ If the individual owner intends to develop or promote his property, he needs assurance that he can do so, not money damages if he cannot. ${ }^{66}$

Even though insurance coverage alone does not adequately protect the insured, the imposition of a duty to search might be undesirable if title companies demanded prohibitive premiums in response to such a duty. The likelihood of this contingency does not seem great. In the first place, so long as the scope of duty imposed is only to make and disclose the findings of a reasonable

64. This may seem "fair" at first glance. The insured has only paid for X dollars worth of protection and this should be the limit of his recovery. While this may be correct for amounts paid for pure insurance protection, it is not true where part of the premium pays for the actual cost of a title search. As the author of Comment, 39 CALIF. L. REv. 235, 247 (1951) points out, neither the risk of loss nor the cost of search increases proportionally with the value of the property. Thus it seems unfair to charge the insured for the cost of a search and then restrict his recovery. See notes 54-56 supra and accompanying text.

On the other hand, to the extent that actual cost in searching title is not used to fix the insurance premium, there may be a subsidy to the owners of very low value or small-percentage-insured property. The actual cost of searching title for such property would probably be prohibitive; utilization of an average dollar cost for both the risk of loss and for expenses incident to searching the title shifts a disproportionate share of expense to the high value and/or high-percentage-insured property owner. See Arnold, Title Evidence in Washington State, Title News, Mar. 1961, pp. 2, 6. But see Spencer, Title Insurance for Cooperative Banks, Title News, June 1960, pp. 16, 20 (insurance must be for full value of property).

Assuming that owners of high value property are better able to bear the cost of insurance and searching, this subsidization may increase alienability of land. See Comment, 39 CALIF. L. REv. 235, 247 \& n.73 (1951); note 84 infra and accompanying text. However, such subsidization may also cause a slight distortion in the best allocation of property if we adopt the highest and best use theory of land use and also a marginal revenue theory of investment. See Bariowe, Land Resource Economics: The Political Economy of RuRal \& URBaN LAND Resource USE 13-15 (1958); see generally id. 112-49.

65. See, e.g., Lawyer's Title Ins. Corp. v. Frieder, -Colo.-, 362 P.2d 555 (1961) (building had to be relocated because of undisclosed easement).

Even if damages were adequate compensation, the inconvenience and delay in filing claims or engaging in a law suit would still remain. See GAGE 52-53 ("The courts are poor media for the collection of damages from the standpoint of the average person.") ; cf. Udell v. City Title Ins. Co., 12 App. Div. 2d 78, 208 N.Y.S.2d 504 (1960) (necessary to engage in lawsuit with third party or have contract of sale rejected before recovery from title company possible).

66. See Johnstone, supra note 57, at 494; McDougal, Title Registration \& Land Reform: A Reply, 8 U. CHI. L. Rev. 63, 70 (1940). This conclusion is painfully borne out by the cases. See, e.g., James Poultry Co. v. City of Nebraska City, 135 Neb. 787, 284 N.W. 273, aff'd, 136 Neb. 456, 286 N.W. 337 (1939) (poultry business upset by zoning restriction); Korn v. Campbell, 192 N.Y. 490, 85 N.E. 687 (1908) (land use limited by restrictive covenant to residential uses); Finley v. Glen, 303 Pa. 131, 154 Atl. 299 (1931) (restrictive covenants prevented building of factory). 
search, there probably will be no great increase in the searching expenses of most title companies. As pointed out above, most reputable title companies already undertake a search and maintain efficient title plants for that purpose. ${ }^{.7}$ Nor are companies which rely upon an attorney's or abstracter's search of title apt to find searching costs greatly increased so long as the scope of search is restricted to that of a reasonable search and care is used in selecting the title searching agent. In the second place, imposing liability for negligent search would probably not increase premiums unduly. The ratio of loss to premiums generally varies from 1.5 to 3 per cent. ${ }^{68}$ Even doubling the amount of loss is thus likely to increase premiums by less than 3 per cent. The occasional title company that attempts to insure on a purely actuarial basis, however, might be seriously affected by such a duty. ${ }^{69}$ But strong policies in favor of free alienability of land suggest that this method of insurance, which may foster further confusion of title by ignoring the possible existence of hidden defects, ${ }^{70}$ should not be indiscriminately encouraged. Finally, even where imposition of a duty would increase searching expenses and liability costs, these increases might not be reflected in higher premiums. In those geographic areas in which there are other institutions assuring titles, competition may partially restrain the prices charged by the insurance companies. ${ }^{71}$ In addition, state regulation may restrict rate increases. ${ }^{72}$ On the other hand, in those areas where title insurance has completely or nearly completely replaced other institutions and in the absence of state regulation of rates, the insurance company would probably shift the added expense.

67. See notes 20-24 supra and accompanying text.

68. The ratio of loss to premiums naturally varies from company to company and from year to year for any given company; in addition, inadequate data prevents a determination of the exact amount of loss. Nonetheless, various surveys, estimates, and reports made to public agencies all indicate the low average ratio of loss to premiums. GaGe 111-14 ("central tendency is not far from ... 1.5\%") ; Huebner, Property Insurance 497 (1922) ("losses paid are trivial") ; Johnstone, supra note 57, at 501 \& n.34 ("national loss ratio for 1954, based on reports of public agencies was 1.69 per cent") ; Comment, 39 CALIF L. REv. 235, 248 (1951) (limited surveys showed averages of $1.5 \%$ in $1920,0.96 \%$ in $1928,3.21 \%$ in 1937; the $3.21 \%$ figure is probably high since it included losses from mortgage guarantee business as well as losses from title insurance business).

69. See note 26 supra.

70. If broadly applied, the typical casualty insurance approach to risk assumption could have a disastrous effect on titles. If title insurance generally were written on a risk basis only, without search or examination, there would be a gradual deterioration in the certainty of titles .... The apparent trend toward more widespread adoption of the casualty approach in title underwriting should be watched with care.

Johnstone, supra note 57 , at 516.

71. See Payne, The Why, What, and How of Uniform Title Standards, 7 ALA. L. REv. 25, 29 (1954) (individual examiner can compete successfully if reforms reduce the burden of examination); Johnstone, supra note 57, at 517; Exchisive or Dual Agencies, Title News, Jan. 1961, pp. 95-101.

72. See Gould, Title Insurance as Viewed from the Aspect of Supervision, Title News, Jan. 1960, pp. 64, 66-68. See generally VILLANova REPoRT $\$ \$ 7.10-.54$. 
Even in the absence of undue increases in insurance premiums, imposition of a duty to search may be undesirable for other reasons. Title insurance companies often "pass" those discovered defects which in the opinion of the insurer will not cause subsequent loss or which are considered so minor as to be de minimis. ${ }^{73}$ Such defects are not entered as exceptions in the title policy. Thus as far as the insured is concerned, these defects do not exist. Placing a duty of search and disclosure upon the title company will compel full disclosure of these defects. Thus, to some extent, the function of evaluating them may be shifted back to the lay owner. This shift seems undesirable since the risks of losing title will loom larger to him than it would to an institution bearing risks on an actuarial basis. ${ }^{74} \mathrm{~A}$ hypertechnical judicial concept of marketability magnifies this potential risk of loss. ${ }^{75}$ Moreover, the private individual can probably expect little aid from the average attorney who, concerned for his reputation in the community, may tread lightly through the ambiguous area of marketability. ${ }^{78}$ As a result, the layman might well seek to clear title with an expensive quiet title suit or else forego an advantageous investment. ${ }^{77}$ To the extent that title companies may remain willing to insure after disclosure, however, these problems of evaluation would be alleviated.

Imposing a duty to search may also frustrate attempts to increase the insurance protection given the insured if the scope of the duty to search is made coextensive with the coverage of the insurance policy. Constant pressure from owners and large investment lenders to expand the scope of coverage has been gradually eroding those areas of blanket exception traditionally found in the early insurance policies. ${ }^{78}$ Title companies are increasingly insuring against such defects as zoning restrictions, mechanics' liens, and tax liens. ${ }^{79}$ Such

73. See Revve 72-73, 77.

74. Gage points out that the risks of loss because of title defects stem from "an element of chance in the search" as well as "from facts which are not to be found within the system of public records." GAGE 34-35. In order to properly gauge such risks, there must be an awareness of the frequency and amounts of loss. See Morris, Enterprise Liability and the Actuarial Process-The Insignificance of Foresight, 70 YALE L.J. 554, 560-67 (1961) ; see generally KuLP, Casualty Insurance 458-532 (3d ed. 1956); Kulp, The Rate-Making Process in Property and Casualty Insurance-Goals, Technics, and Limits, 15 LAw \& Contearp. Prob. 493 (1950). The layman does not have the awareness nor does he experience sufficient losses from defects to develop such awareness.

75. Basye $\$ 3$, at $6, \S 5$, at 16-17; Dungans, Modern Real Estate Transactions 629 (2d ed. 1958) ; Morton, New Horizons, Title News, Jan. 1960, pp. 11, 17; cf. Townshend v. Goodfellow, 40 Minn. 312, 316, 41 N.W. 1056, 1057 (1889); Douglass v. Ransom, 205 Wis. 439, 237 N.W. 260 (1931).

76. See BASYE $\&$, at 16-17.

77. Id. $\$ 203$, at 294; Comment, Enhancing the Marketability of Land: The Suit to Quict Title, 68 Y ALE L.J. 1245 (1959).

78. See VILlanova REPORT $\$ 0.20$, at 11-12; Vietmeyer, "Reflections of a Customer," Title News, Jan. 1961, pp. 126, 128-29; Schmidt, Title Losses, Title News, Jan. 1959, p. 27.

79. Institutional investors expect their owner's policy, as does the mortgagee policy to afford protection against mechanics' liens, parties in possession, survey readings and marketability. Currently, a substantial volume of the policies offered to investors 
defects may well pose the largest threats of restricted use and potential loss to the owner. ${ }^{80}$ Yet these are the areas in which discovery is most difficult. ${ }^{81}$ Finding a duty to search those areas in which there has been an undertaking to insure may well prevent or even reverse increases in insurance coverage. The cost of searching may be prohibitive. ${ }^{82} \mathrm{Or}$ the possibility that a court may adopt a tort theory of liability for negligent search and award damages greater than the face amount of the policy may preclude accurate actuarial treatment of the risks, thereby curtailing the companies' expansion of insurance protection in these areas. ${ }^{83}$ To the extent that questions of reasonable

must be returned for a more satisfactory policy form or for the elimination of unacceptable exceptions.

Bonnin, Mutuality of Interest, Title News, Jan. 1959, pp. 119, 125; REEve 60, 80; Report of Chairman, Southwest Region, Title News, Jan. 1960, p. 74. But see Henley, The New Title Insurance Policy Form, Title News, Sept. 1960, pp. 2, 7-8 (ATA Uniform Policy does not insure against zoning despite investor pressures).

80. See, e.g., Comment, 39 CALIF. L. Rev. 235, 238 (1951) (tax liens); Henley, supra note 79 , at 7 (zoning restrictions).

81. See Henley, supra note 79, at 7 (noting difficulties in protecting from zoning restrictions). Because mechanics' liens may attach to property prior to filing or may relate back to a time earlier than the date of filing, discovery may be nearly impossible. Physical inspection of the property as well as search of the public records is necessary to discover these defects. See Comment, 68 Yale L.J. 138, 152, 155 (1958). State tax liens, since mere assessment of the tax may give rise to a lien, necessitate an extensive examination of current tax rolls, inquiries about possible gift or estate taxes, and a search of past tax records. Even though general federal tax liens must be filed before becoming valid against subsequent purchasers and mortgagees, the common practice of filing "blanket" notices covering all the property of a taxpayer without any specific reference to or description of property makes their discovery particularly difficult. See Wright, Title Examinations in Michigan as Affected by the General Federal Tax Lien, 51 Micr. L. REv. 183-86, 192-99 (1953) ; Core, Tax Forfeiture Problems in the Examination of Abstracts, 12 ARK. L. REv. 333 (1958). Special federal gift and estate tax liens are also particularly troublesome. Ascertainment of the time and manner of attaching as well as determination of what property is covered by such liens may be nearly impossible. See Wright, supra at 325-26, 335-40 (1953).

82. To the extent that the title company must look outside its own records to discover defects, costs may be prohibitive. See GAGE 87-89. However, insofar as extraneous matters can be put upon the company's records in the title plant, the costs of discovering such defects should not prove unduly high. See $i d$. at 87. And since it appears that "losses which arise from a non-record origin are considerably less important than those which arise from the record," there probably need not be "any great increase in rates on policies which cover every contingency." Id. at 131. See text accompanying notes 67-69 supra.

83. So long as the insurer can limit its maximum possible liability, it is possible to prorate premiums on this amount. Where, however, there is no maximum, the insurer has no basis upon which to set its premium. See Spencer, Title Insurance for Co-operative Banks, Title News, June 1960, pp. 16, 20 :

[T] he title companies must require the owner to take out a policy which covers the value of his property. Actuarially, it would not be feasible to permit the owner of a property worth $\$ 100,000$ to carry only $\$ 20,000$ of title insurance.

If the scope of insurance coverage is not used to control (broaden) the scope of a reasonable search, tort liability for negligent search can be imposed even while allowing the insurer to set a maximum on liability under the insurance coverage. 
search are kept separate from the scope of insurance coverage, however, these dangers can be avoided.

The inadequacy of insurance coverage alone and the importance of disclosure to the individual owner thus appears to outweigh the disadvantages of imposing a duty to search. The soundness of this conclusion becomes more evident when the interests of society in general are considered. To protect society adequately a method of assuring title should at least increase the unrestricted alienation of land, 84 facilitate the determination of the nature and extent of existing rights in land, ${ }^{85}$ and facilitate efficient risk and resource allocation. ${ }^{86}$ These broad objectives are, of course, interrelated. Determining the nature and extent of the rights existent in land will allow freer transfer of these rights. Disclosure of rights held by others or disclosure of restrictions on the use of land will facilitate efficient resource allocation. Reduction of the risks from undiscovered title defects fosters more certain analysis and planning which in turn will lead to greater economic efficiency in the use of land. ${ }^{87}$ It seems self-evident, given our present recordation system, that an adequate title search is necessary to determine the nature and extent of existing rights in land. It also seems obvious that there must be a determination of the quantum of rights which are being bought and sold in order to bring about free alienation of these rights. In order for investors, owners, developers, and promoters to act wisely-that is, in order to have efficient allocation of land resources in our private enterprise economy-there must be disclosure of the rights and restrictions upon the property being developed. A prospective businessman must have assurance that he can indeed sell his wares and that customers will have easy access to his contemplated location before he can make an intelligent choice of a business site. To effectuate these social interests and individual needs, insurance coverage alone is inadequate; a duty to search title and disclose defects must also be imposed.

Despite the desirability of a title search, courts, because of the doctrine of freedom of contract, may well be reluctant to overturn clear exculpatory clauses and find a duty to search outside of express contractual terms and the factual circumstances surrounding them. ${ }^{88}$ Freedom of contract, however,

84. See Basye $\$ 1$, at 3 , § 374; McDougal \& Haber, Property, Wealth Land: Allocation, Planning \& Development 78-80 (1948); North \& Van Buren 243; Gage 11-14.

85. See McDougal \& HABER, op. cit. supra note 84, at 78; Basye, Improvement of Conveyancing Procedure, 36 NEB. L. Rev. 81, 82 (1957); Payne, The Crisis in Conveyancing, 19 Mo. L. REv. 214, 216 (1954).

86. GAGE 14-15, 148; McDougAL \& HABER, op. cit. supra note 84, at 42-43; Vietmeyer, "Refictions of a Customer," Title News, Jan. 1961, pp. 126, 129.

87. Insurance itself is, of course, of major importance in facilitating this broad goal.

88. See, e.g., Knouse v. Equitable Life Ins. Co. of Iowa, $163 \mathrm{Kan} .213,216,181$ P.2d 310,312 (1947) ("may not make another contract for the parties"); Union Realty Co. v. Ahern, 93 A.2d 84 (D.C. Munic. App. 1952) (court refused to hold company liable because of disclaimer of responsibility for correctness of information relating to taxes and assessments); Evans v. Metropolitan Life Ins. Co., 26 Wash. 2d 594, 604, 174 P.2d 961, 967 
is not an absolute. The social interest in disclosure, the fact that title companies do commonly make a search, and the weak economic power of the typical private buyer or seller of land, all combine to recommend the third approach set forth at the beginning of this Note-finding in the relationship of the parties a duty to search title. In this regard there is a spectrum of positions which courts might take and to varying degrees have taken when faced with standardized mass contracts written by large scale enterprises.

Courts, under the guise of interpretation, have attempted to redress the inequities resulting from standardized contracts either by strictly construing the contract against the maker ${ }^{89}$ or by purposely creating ambiguity where there is no ambiguity so that the fictional void could be filled with a just result. ${ }^{90}$ Decisions in title insurance cases manifest both these approaches. ${ }^{01}$ It may be doubted, however, whether either approach is wholly desirable. Strictly construing the policy against the insurer seems warranted in the situation of an owner's policy where the insurer's bargaining power and economic strength is typically far greater than that of the average disorganized and unknowing owner. ${ }^{92}$ In the mortgagee policy situation, however, the stronger bargaining

(1946) ("a court is not at liberty to revise a contract under theory of construing it; . . . neither abstract justice, nor any rule of construction, justifies the creation of a contract" not made by the parties).

89. The rule [of construction against the maker] is hardly to be regarded as truly a rule of interpretation; its application does not help to determine the meaning that the two parties gave to the words, or even the meaning that a reasonable person would have given to the language used. It is chiefly a rule of public policy, generally favoring the under dog.

3 Corbin, Contracts $\$ 559$, at 268-70 (2d ed. 1960).

90. See Llewellyn, What Price Contract?-An Essay in Perspective, 40 Yale L.J. 704, 732-34 (1931); Llewellyn, Book Review, 52 HaRv. L. Rev. 700, $702-03$ (1939); cf. 3 Corbin, Contracts $\$ 534$, at 11-12 (2d ed. 1960).

91. Construction against the maker. See, e.g., Miller v. Lawyers Title Ins. Corp., 112 F. Supp. 221, 225 (E.D. Va. 1953) ; National Holding Co. v. Title Ins. \& Trust Co., 45 Cal. App. 2d 215, 113 P.2d 906 (1941) ; Houston Title Guar. Co. v. Fontenot, 339 S.W.2d 347, 350 (Tex. Civ. App. 1960).

Creation of ambiguity. See, e.g., Place v. St. Paul Title Ins. \& Trust Co., 67 Minn. 126, 69 N.W. 706 (1897) (adverse possession rights were not excepted by clause excluding defects because of "tenancy by the present occupants") ; Henkels v. Philadelphia Title Ins. Co., $177 \mathrm{~Pa}$. Super. 110, 110 A.2d 878 (1955) (statement in title certificate clearly excepting property subject to a tax lien held to be exception for insurance coverage only and not for duty to search); Marandino v. Lawyers' Title Ins. Corp., 156 Va. 696, 159 S.E. 181 (1931) (insurer held to have assumed risk of faulty description by describing property in insurance policy and noting ordinance which took some of insured's property).

92. The relatively small number of title companies, the high expense required in setting up adequate search facilities, and the large volume of business done by major companies give title insurers a natural monopoly and all the power that entails. GAGE 150. The number of title insurance companies operating in the United States has been estimated at between 160 and 180. Grimes, The Lawyer, His Client and Title Insurance, Title News, Sept. 1958, pp. 2, 5. The volume of business is sometimes staggering: Chicago Title and Trust Company, for example, has issued over 5 million policies. Title Milestones, Title News, 
power is apt to be possessed by the insured-usually a large, well-organized institutional lender-rather than by the insurer. The insured is often instrumental in dictating the terms of the contract or even in writing the policy itself. ${ }^{93}$ In such a case the application of a uniform rule of construction against the apparent "maker" of the contract is not warranted. Nor does judicial creation of ambiguity seem a desirable response. In the first place society has to pay a high price in the form of increased litigation for the resulting uncertainty in the law. ${ }^{94}$ In the second place this "interpretation" device results in a constant struggle between draftsmen of standardized contracts and the courts. Contract clauses become longer and more complex as draftsmen attempt to keep one step ahead of adventuresome courts. ${ }^{95}$ Such complexity in drafting may well leave the insured less and less aware of what it is that is being promised. It may also lead to ambiguities and inconsistencies which will provide greater room for justifiable court intervention.

A far more desirable approach is that suggested by Professor Kessler's well-known article on contracts of adhesion. ${ }^{96}$ The article points to the inadequacy of judicial attempts to maintain the unity of the law of contracts in the face of widespread use of standardized "contracts of adhesion" and admonishes the courts that the "task of adjusting . . . the common law of contracts to contracts of adhesion has to be faced squarely and not indirectly." ${ }^{\prime 27}$ The mortgagee policy of title insurance seems generally the product of true bilateral bargaining, and courts should continue to respect the terms which the parties have negotiated. The individual owner's title policy, however, seems a typical situation of adhesion where the "choice" of the individual is limited to taking or leaving what he is given. Here the courts should not be hesitant, even while restricting themselves to a contract theory,

Feb. 1960, pp. 28-29. See Johnstone, supra note 57, at 492 \& n.4, $505 \&$ nn.51-52 (dollar volumes and operating areas). In contrast to this institutional strength the typical owner has little power or experience. See Dunham, Modern Real Estate Transactions 283-85 (2d ed. 1958).

93. See Johnstone, supra note 57, at 502-05. Henley's historical analysis of the development of the A.T.A.'s uniform policies provides an illustration of the methods by which large institutional lenders exercise their great bargaining strength constantly to expand the scope of policies written for their benefit. Henley, The New Title Insurance Policy Form, Title News, Sept. 1960, pp. 2, 49.

94. See Llewellyn, What Price Contract?-An Essay in Perspective, 40 YaLE L.J. 704, 732 (1931) :

'[C]onstruing' the particular language in question not to have intended the result it did intend ... kills security in transactions, if 'security' means predictability of actions at law. No man is safe when language is to be read in the teeth of its intent. Nor is even the party who is being protected safe, this side of final judgment, in having got what he thinks he has bought....

95. Id. at 732-34 ("Meantime the greater bargainor, defeated once and again, recurs to the attack. After each case he can redraft and fight again.") ; Kessler, Contracts of Adhesion -Some Thoughts About Freedom of Contract, 43 Colus. L. REv. 629 (1943).

96. Kessler, supra note 95.

97. Id. at 637. 
to rewrite the insurance policy in order to reflect the relationship between the typical owner and the typical insurer. ${ }^{98}$ By recognizing the needs and expectations of the individual owner, ${ }^{99}$ his lack of bargaining power, ${ }^{100}$ and the social implications of the owner-insurer relationship, ${ }^{101}$ a court reasonably and legitimately could read into the title policy an implied-in-law promise to search title with due care-a promise which should not be subject to exculpation. ${ }^{102}$ The same technique might be described in terms of tort doctrine as imposing a status relationship on the parties and finding in that relationship a duty of the insurer to search and disclose. ${ }^{103}$ Adhesion contracts in the field of title insurance, as in other growing areas of the law, ${ }^{104}$ exert pressure on the thin conceptual line between tort and contract, and perhaps raise questions as to the utility of such a line. ${ }^{105}$ Whichever doctrinal formulation is employed, the judicial establishment of a duty to search will, at small cost to the insurer, provide the individual owner with information necessary for his protection and enable him to take prudent investment action.

Finding or imposing a duty to search, however, merely begins the job. A court must also define the scope of a reasonable search and must resolve the problems of what kind of liability should be imposed for breach of the duty to search. As indicated above, the scope of a reasonable search should not be made co-extensive with the areas insured against since such a definition might

98. There are, of course, powerful institutional owners and weak, disorganized lenders. But if a workable judicial rule is to be adopted-a rule on which both insureds and insurers may rely in their relationship-categories or classes rather than particular persons must be considered in determining relative bargaining power. See 6 Wizliston, Contracts $\$ 1751 C$, at 4968 (rev. ed. 1938) ; cf. text accompanying notes $48-49$ supra.

99. Applicants for a title insurance policy are interested in obtaining the insurance coverage but they are sometimes more interested in what the company's examination of title disclosures.

Johnstone, supra note 57, at 494. See GAGE 11.

100. See note 92 supra and accompanying text.

101. See notes 84-87 supra and accompanying text.

102. See note $\mathbf{5 2}$ supra.

103. See Prosser, Torts $\$ 1$, at 5 (2d ed. 1955); Seavey, Principles of Torts, $56 \mathrm{HARv}$. L. REv. 72, 75-77 (1942).

104. Compare the breakdown in warranty cases of the common law contractual concept that only those persons who are parties to a bargain can sue for breach of it. This movement from contract to status is ably discussed and aptly climaxed in Henningsen v. Bloomfield Motors, Inc., 32 N.J. 358, 161 A.2d 69 (1960).

105. There are various relationships similar to that of title insurer and insured which will support either a tort or a contract theory of liability. See Prosser, TorTs § 81 (2d ed. 1955). The judicial confusion resulting from this ambiguity has produced "a forest of flat, stale, and unprofitable cases." Prosser, The Borderland of Tort and Contract, in SELECTED Topics on the LAw of Torts 433 (1954). Some of the confusion may be ascribed to the historical development of these two theories from their common ancestor-the common law of trespass. $I d$. at $380-85$. Perhaps the only real utility in the line is the verbal leverage it gives courts for effectuating desirable policies. See Comment, 14 BrookLyN L. Rev. 196, $197-98,213$ (1948). 
curtail the expansion of casualty protection. ${ }^{106}$ Moreover, if a reasonable search were held to include such difficult-to-discover items as tax liens and zoning restrictions, title insurance companies might find themselves forced to charge prohibitive premiums. ${ }^{107}$ Items which fall clearly outside of those sources that a typical searcher would consult thus should not be read into a legally-imposed duty. As to such items the insured will have to rely on insurance protection or purchase additional search at a separate cost. ${ }^{108}$ In the inevitable area of ambiguity between items clearly included in and items clearly excluded from a reasonable search the courts must inquire into the economic feasibility of discovering various types of defects. As this inquiry takes place case by case, both title insurance companies and their insureds will have an opportunity to put forth their views fully, and the outlines of a reasonable search can be delineated pramatically and flexibly. ${ }^{108}$

In resolving the problem of what kind of liability should be imposed for breach of a duty to search, a court must choose between contract and tort theories. Since under either theory of liability the complaint will usually speak in terms of negligent action, a court must be careful not to confuse the preliminary question of whether the insurer is liable for a negligent search with the later question of whether that liability is contractual or tortious in nature. Many of the cases seem to have confused these two issues. ${ }^{110}$ Allegations of negligent action should not lead automatically to adoption of a tort or "negligence" theory of liability. Inasmuch as the duty to use reasonable care is ultimately grounded in the insurance contract relationship, contract liability is equally appropriate. As with the choice of the theory to adopt in imposing a duty to search, ${ }^{111}$ the choice here seems essentially arbitrary. And if both choices are abitrary, the theory adopted in resolving the preliminary issue can afford no assistance in deciding which theory of liability to adopt. Equally inconclusive is the line of reasoning adopted by some courts in the past that the liability of title insurers for negligent search should, by analogy,

106. See notes 78-83 supra and accompanying text.

107. See note 82 and text accompanying notes 67-69 supra.

108. Special searches and other services are already being provided for the insured at an additional cost. For example, the title company may undertake foreclosure searches, judgment searches, or tax searches. See NoRTH \& VAN BUREN 258-59.

109. Cf. Falcone v. Middlesex County Medical Soc'y, 34 N.J. 582, 596, 170 A.2d 791, 799 (1961) ("step by step process affords the light of continued experience to guide [the law's] future course"); Walker, Inc. v. Borough of Stanhope, 23 N.J. 657, 666, 130 A.2d 372, 377 (1957).

Among the relevant guides to defining the scope of a reasonable search would be the searching practices and searching facilities which prevail in the community in question. One of the best guides might be the local bar associations' prevailing title standards. See, e.g., Basye, Improvement of Conveyancing Procedure, 36 NEB. L. REV. 81, 90-92 (1956).

110. See, e.g., M.R.M. Realty Co. v. Title Guar. \& Trust Co., 270 N.Y. 120, 125, 200 N.E. 666, 667-68 (1936) ; Sperling v. Title Guar. \& Trust Co., 227 App. Div. 5, 10, 236 N.Y. Supp. 553, 558-59 (1929).

111. See notes $98-105$ supra and accompanying text. 
be the same as that of their predecessors $:^{112}$ the liability of an abstracter has generally been treated as contractual in nature while that of an attorney has sounded in tort. ${ }^{113}$ With such uncertainty it might seem that the arguments of counsel would eventually prove conclusive. Here again, however, since both theories offer litigation advantages, ${ }^{114}$ no exact answer can be given as to the liability which should be adopted. This situation seemingly allows a court

112. See, e.g., Sandler v. New Jersey Realty Title Ins. Co., 66 N.J. Super. 597, 169 A.2d 735 (1961) ; Glyn v. Title Guarantee \& Trust Co., 132 App. Div. 859, 117 N.Y. Supp. 424 (1909) ; Ehmer v. Title Guarantee \& Trust Co., 156 N.Y. 10, 34 N.Y. Supp. 1132, 50 N.E. 420 (1898) ; Henkels v. Philadelphia Title Ins. Co., 177 Pa. Super. 110, 110 A.2d 878 (1955). See note 45 supra and accompanying text.

113. Why this distinction should exist is unclear. It is clear, however, that the bulk of litigation against abstracters has proceeded on a theory of contract. WARVELIE, ABSTRACTS \& Examinations of Title to Real Property \$ 10 (4th ed. 1921); Roady, Professional Liability of Abstracters, 12 VAND. L. REv. 783, 784 (1959); Title Symposium: Abstractor's [sic] Liability in Examination of Title, 6 Wro. L.J. 184 (1952) ; Annot., 28 A.L.R.2d 891, 900 (1953) ("With only occasional dissent, the cases agree that the liability of the abstractor is purely contractual.") While the attorney's liability similarly arises out of a contractual relationship, it more frequently sounds in tort than in contract. See Wade, The Attorney's Liability for Negligence, 12 VAND. L. Rev. 755, 757 (1959) ; Title Symposium: Attorney's Liability in Title Examination, 6 Wxo. L. Rev. 171 \& n.1 (1952); Isaacs, Liability of the Lawyer for Bad Advice, 24 CAIIF. L. Rev. 39 (1935); Annot., 5 A.L.R. 1389 (1920). Wade states that this issue "has not troubled the courts often and [that] there has been little discussion of it." Wade, supra at 756 \& n. 10 .

114. Contract, for example, may entail a lesser burden of pleading and proof since liability will attach on a showing of the mere existence of an encumbrance on the property, whereas a tort action would require proof of negligence or some other wrongful conduct in the search of title. See, e.g., Glickman v. Home Title Guar. Co., 8 Misc. 2d 303, 167 N.Y.S.2d 793 (1957) ; Empire Dev. Co. v. Title Guar. \& Trust Co., 225 N.Y. 53, 121 N.E. 468 (1918). Similarly there may be no need to prove reliance. See Maggio v. Abstract Title \& Mortgage Corp., 277 App. Div. 940, 98 N.Y.S.2d 1011 (1950). A longer statute of limitations may allow contractual recovery even after the tort action has been barred. Cf. Manning v. 1234 Corp., 174 Misc. 36, 20 N.Y.S.2d 121 (1940) (whether assault and battery action under tort or under contract). This advantage may be relatively unimportant in suits against title insurance companies as compared to suits against title attorneys or abstracters since the statute of limitations for negligent search usually does not begin to run against title companies until the overlooked defect or encumbrance is discovered; in comparison, the statute of limitations usually begins to run against title attorneys and abstracters when the faulty title opinion or abstract is given even though an action cannot be brought until actual damage or loss has been suffered. Title Symposium: Attorneys' Liability in Title Examination, stpra, at 186 \& n.26; Roady, supra note 113, at 792-93. Other potential advantages of contract theory may be recovery of loss of bargain damages where these might exceed damages recoverable in tort, recovery of interest from the date of the breach, survival of the action, additional remedies such as summary judgment or attachment, and greater opportunities for forum shopping.

Generally speaking, the greatest advantage in suing in tort comes from the likelihood of greater damages. The limitations imposed by the contract on the maximum damages recoverable may be avoided by suing in tort. See, e.g., Quigley v. St. Paul Title Ins. \& Trust Co., 60 Minn. 275, 62 N.W. 287 (1895) ; Annot., 60 A.L.R.2d 972 (1958). In addition the potentially wider scope of proximate cause under a tort theory may extend to items not in- 
to choose the theory which most clearly effectuates desirable social action. Tort theory, in that it offers potentially greater damages and perhaps provides a wider scope of duty, would seem to be more effective in forcing title companies to make a diligent search. ${ }^{115}$ However, care should be taken to limit tort liability to situations in which there is a showing of negligence. Liability must be hinged to the concept of a reasonable search, and when defects are of a type not reasonably discovered no liability should be imposed. ${ }^{110}$ This limitation will leave treatment of undiscoverable defects to the insurance function and thereby promote efficient risk analysis and risk spreading without unnecessarily reducing the expansion of casualty insurance coverage.

Judicial conservatism may necessitate legislation. A court may refuse to impose a duty because such a duty is contrary to the clear intent of the insurer, or because it feels incapable of defining an economically reasonable search. One legislative response might be to place in a regulatory agency the tasks of defining and enforcing a reasonable search for the benefit of the recipients of title insurance. Insurance commissions are already beginning to take an active role in the regulation of title insurance. ${ }^{117}$ Yet the difficulties of securing legislation in states where title companies maintain strong lobbies, the problems of keeping a specialized agency independent of the institution regulated, and the competence of courts to handle delicate problems of reasonableness on a scale of community standards, combine to suggest that control in this area be left with the judiciary. Where it is possible to secure legislation, it should be drawn in general terms. Overly detailed legislation may crystallize institutional standards and practices, thereby hindering the development of new searching methods. ${ }^{118} \mathrm{~A}$ statement that a title insurer must make a reasonable title search and must reveal to the insured all defects discovered prior to

cludable under a contract theory; a tort theory may permit the plaintiff to avoid possible set-offs or counterclaims; and tort recovery may be possible where a contract action would fail for lack of proof. See Prosser, Torts \$ 81, at 483-86 (2d ed. 1955).

115. See note 114 supra. Not only will tort theory provide more adequate protection to the insured and greater incentive toward a careful search on the part of the insurer because of its potentially greater damages, but it may also provide the courts with a more flexible instrument in effecting their task of defining a reasonable search. Cf. Dorr v. Massachusetts Title Ins. Co., 23 Mass. 490, 131 N.E. 191 (1921) (tort recovery for defects expressly excepted from the insurance policy where surrounding circumstances were such that the company should have given notice of the defect to the insured before the policy was issued) ; Ehmer v. Title Guar. \& Trust Co., 156 N.Y. 10, 50 N.E. 420 (1898) (tort recovery where insurance contract issued for wrong property and contract recovery was thereby precluded).

116. See text accompanying notes 106-09 supra.

117. See VIllanova Report $\$ \S 1.10,1.31$. Most regulation has been directed toward ensuring financial responsibility. Id. at \$\$ 6.10-.90. Regulation may also take place through the indirect method of licensing requirements. Id. at $\$ \S 4.10-.40$.

118. Consider, for example, the increasing use and development of microfilm and photographic techniques for the "take-off" (copying) of public records. Waddell, Record Creation and Retention, Title News, Mar. 1961, p. 26; Shedd, Microfilm Take-Offs, Title News, July 1960, p. 19. 
issuing a policy of insurance should suffice. ${ }^{119}$ Such a directive would ensure the imposition of a duty to search while leaving the delicate task of defining the "reasonable search" to the courts, where primary responsibility in this area-with or without express legislative support-should remain.

119. Past legislation concerning title insurance indicates there is great danger of poor draftsmanship in the title insurance area. See, e.g., BASYE § 5, at 18-19 ("sporadic and not systematic, restrictive and not comprehensive"); Burlingame, Villanova Project Report, Title News, Jan. 1961, pp. 23-24 ("in all but a few instances legislative bodies have avoided any sensible or coherent pattern in adopting legislation").

A recent statute enacted as compromise legislation, even though written in general terms, manifests some of these shortcomings:

Nothing in this subdivision shall authorize an insurance company to issue a policy of title insurance in this state until the applicant therefor has been notified in writing by such company of all defects in title which will be excluded from coverage under the prospective policy. Such notice shall set forth in descriptive terms the nature of such excluded defects. Upon receipt of such notice, the applicant shall have the option of cancelling his application without any liability therefor to said company.

VT. Stat. Ann. tit. 8, § 3301(7) (Supp. 1961). For the history and an evaluation of this legislation see Rawlings, Report of Chairman of Title Insurance Section, Title News, Jan. 1960, pp. 54-55. The language of the statute itself is ambiguous. Insofar as it suggests that the title insurer must make a search prior to the issuance of insurance it is sound. If, on the other hand, the statute is interpreted merely to require that the company state the areas of blanket exception, it will be inadequate. It also seems inadequate in that it possibly fails to allow the insurer to charge for a search in the event that insurance is not issued. Even though the statute provides for judicial definition of the duty to search, the fact that the duty has been legislatively imposed should prevent exculpation since exculpation of a statutory duty is generally not allowed. 6 WILLISTON, ConTRACrs $\$ 1751 \mathrm{~B}$, at 4966 (rev. ed. 1936). 